\title{
Recurrent T-Cell Non-Hodgkin Lymphoma
}

National Cancer Institute

\section{Source}

National Cancer Institute. Recurrent T-Cell Non-Hodgkin Lymphoma. NCI Thesaurus.

Code C8663.

The reemergence of $\mathrm{T}$-cell non-Hodgkin lymphoma after a period of remission. 